\title{
UPAYA MENCEGAH PAHAM RADIKAL DAN INTOLERANSI MELALUI WORKSHOP PENERJEMAHAN NASH KEAGAMAAN BAGI PARA DA'I DI KABUPATEN SUBANG
}

\author{
Asep Sopian \& Mad Ali \\ Universitas Pendidikan Indonesia \\ aseepsopian@upi.edu
}

\begin{abstract}
There are still plenty of radicalism and intolerance in Indonesia, like suicide bombing, Bali bombing, police station attacks and so on. The Managing Director of Wahid Institutes, Yenny Wahid (2017) said that the survey's results show that there is an increase in radical understanding in Indonesia, numbering 600,000 or 0.4 percent of Indonesia's population. A misinterpretation of religious texts and particularly those concerning the theme of jihad is a contributing factor. The method of service is conducted through workshops and seminars. After the priests took part, they gained new positive insights into the spread of Pesantren deradicalization and tolerance.
\end{abstract}

Keyword: Paham Radikal, Intoleransi, Penerjemahan, Nash Keagamaan

\section{Pendahuluan}

Praktik radikalisme dan intoleran kerap ditemui di Indonesia, atau di negara-negara lain. Hal ini setidaknya dipicu oleh berbagai kondisi di antaranya karena adanya tesis Samuel P. Huntington dalam e Clash of Civilizations and the Remaking of World Order yang menyatakan bahwa berakhirnya Perang Dingin yang ditandai dengan runtuhnya ideologi 
komunisme, wilayah konflik meluas melewati fase Barat, dan yang mewarnainya adalah hubungan antara peradaban Barat dan non-Barat serta antarperadaban nonBarat itu sendiri. Huntington mengelompokkan negara-negara bukan atas dasar sistem politik ekonomi, tetapi lebih berdasarkan budaya dan peradaban. Ia mengidentifikasi sembilan peradaban kontemporer, yaitu, peradaban Barat, Cina, Jepang, Amerika Latin, Afrika, Hindu, Budha, Islam, dan Kristen Ortodoks. Benturan yang paling keras - menurut Huntington akan terjadi antara kebudayaan Kristen Barat dengan kebudayaan Islam. Tesis tersebut secara tidak langsung memperkuat asumsi sebagian besar ilmuwan Barat yang melihat Islam sebagai aggression and hostility (agresi dan ancaman). Pendek kata, bagaimana Barat menciptakan stereotipe-stereotipe simplistis yang menunjukkan wajah the rage of Islam. $^{1}$

Latar belakang pemikiran Huntington di awali dari satu hipotesis bahwa sumber fundamental dari konflik dalam dunia baru - yang dimaksud adalah dunia pasca perang dingin - pada dasarnya tidak lagi ideologi atau ekonomi, melainkan budaya. Masa Perang Dingin adalah konflik antara dua negara super power yang tidak lagi mendefinisikan

${ }^{1}$ Vita, Fitria. Konflik Peradaban Samuel P. Huntington (Kebangkitan Islam yang Dirisaukan?), Humanika Vol. 9 (1), Maret (2009), 39-52. Tersedia online:https://media.neliti.com/media/publications/18122-ID-konflikperadabansamuel-p-huntington-kebangkitan-islam-yang-dirisaukan.pdf 
diri masing-masing sebagai negara bangsa dalam pengertian klasik, tetapi mendefinisikan identitas masing-masing atas dasar ideologi yang mereka anut (komunis dan demokrasi liberal). ${ }^{2}$

Zuhairi Misrawi menyimpulkan bahwa munculnya radikalisme dan intolensi bukan hanya disebabkan oleh tesis Huntington di atas, tetapi menurutnya ada dua faktor utama yang menyebabknnya. Pertama, faktor internal, yakni pemahaman keagamaan yang dangkal, sempit, dan kadang kala picik. Kedua, faktor eksternal. Harus diakui bahawa ketidakadilan sosial dan ketidak adilan global juga turut melahirkan munculnya sikap intoleran dalam tradisi agama-agama pada umumnya, khususnya Islam. ${ }^{3}$

Di Indonesia terjadi berbagai peristiwa radikalisme seperti berbagai peristiwa bom bunuh diri, bom Bali, dan sebagainya. Direktur Eksekutif Wahid Institute Yenny Wahid mengatakan banyak sekali survei nasional yang telah dilakukan Wahid Institute terkait radikalisme agama. Berdasarkan hasil survei itu, paham radikal di Indonesia semakin mengalami peningkatan. Yenny mengatakan, peningkatan

2 Vita, Fitria. Konflik Peradaban Samuel P. Huntington (Kebangkitan Islam yang Dirisaukan?), Humanika Vol. 9 (1), Maret (2009), 39-52. Tersedia online:https://media.neliti.com/media/publications/18122-ID-konflikperadabansamuel-p-huntington-kebangkitan-islam-yang-dirisaukan.pdf

${ }^{3}$ Misrawi, Zuhairi. Ke Arah Islam Rahmatan Lil "Alamin, Tantangan dan Jawaban, dalam Seminar Islam Agama Dialogis dan Cinta Damai, 20 Januari 2013. 
tindakan radikal tersebut cukup banyak dan hal itu disebabkan oleh beberapa faktor. Berdasarkan hasil survei, kata dia, orang yang telah melakukan tindakan radikal di Indonesia ada sekitar 600 ribu orang atau 0,4 persen dari jumlah penduduk Indonesia. ${ }^{4}$

Kondisi di atas, sangat mempihatinkan sebab bisa mengancam keutuhan dan kedaulatan bangsa Indonesia. Oleh karena itu perlu dilakukan upaya pencegahan yang serius dan massif untuk meminimalisirnya, di antaranya melalui pelatihan dan workshop penerjemahan nash keagamaan. Penerjemahan berkaitan erat dengan kebudayaan. Suatu kebudayaan tidak lahir dari kekosongan. Ia didahului oleh kebudayaan-kebudayaan lain yang menjadi unsur pembentuknya. Kebudayaan suatu bangsa selalu merupakan ikhtisar dari kebudayaan sebelumnya atau seleksi dari berbagai kebudayaan lain. Dengan demikian kebudayaan dapat dipandang sebagai proses memberi dan menerima.

Penerimaan atau penyerapan suatu kebudayaan dilakukan oleh suatu masyarakat yang ingin meningkatkan kualitas dirinya dan kesejahteraan hidupnya. Karena itu, mereka mengambil sistem pendidikan dari negara maju, karena masyarakat itu yakin bahwa

4 Yenny, Wahid. Radikalisme di Indonesia Meningkat. https://www.republika.co.id/berita/nasional/umum/17/03/27/onh8yv366-yennywahid-radikalisme-di-indonesia-meningkat, 2017. 
kualitas diri dan kesejahteraan diraih melalui pendidikan. Demikian pula dengan sistem ekonomi, bahkan sistem politik suatu negara dimanfaatkan oleh bangsa lain.

Mungkin pula pembentukan kebudayaan dilakukan melalui peniruan suatu masyarakat atas budaya lain yang dianggap baik dan mapan. Pembentukan kebudayaan melalui proses peniruan dapat terjadi secara selektif atau secara sepontan. Cara yang pertama dilakukan melalui proses berpikir kritis, selektif, dan kontekstual. Artinya, kebudayaan masyarakat lain itu diseleksi dan ditapis selaras dengan kebutuhan dan konteks masyarakat penerima.

Proses pembentukan kebudayaan di atas terjadi dan berkembang melalui berbagai sarana, di antaranya sarana pendidikan dan penerjemahan buku dan dokumen yang memuat kebudayaan suatu bangsa. Catatan sejarah menunjukkan bahwa sebagian kebudayaan dan peradaban Islam pertama-tama berkembang melalui penerjemahan karya-karya lama Yunani, Persia, India, dan Mesir dalam bidang ilmu eksakta dan kedokteran. Kegiatan ini dimulai pada masa pemerintahan Khalifah Abu Ja'far al-Mansur (137-159 H./754-775 M.), seorang khalifah dari Dinasti Abbasiah. Upayanya itu mencapai kegairahan yang menakjubkan pada masa Khalifah al-Ma'mun sehingga mengantarkan umat Islam ke masa keemasan (Majid, 1997: 98-99).

Indonesia terfokus pada nas-nas keagamaan, mulai dari kitab 
suci Alquran, Hadits, dan tafsir hingga buku-buku tentang dakwah, akhlak, dan yang menelaah aneka pemikiran keislaman. Kondisi demikian dapat dimaklumi karena masyarakat Indonesia sangat membutuhkan ilmu agama guna mengisi, melengkapi, dan menyempurnakan praktik keislaman mereka secara utuh dalam segala dimensinya. Kenyataan ini semakin menguatkan pandangan bahwa penerjemahan yang dilakukan oleh suatu masyarakat hanyalah berkenaan dengan suatu bidang yang tidak dimilikinya, tetapi sangat dibutuhkannya, dan bidang itu dimiliki oleh masyarakat lain serta ditulis dengan bahasa mereka sendiri.

Karena bidang keislaman itu dibutuhkan, sebagian orang Islam yang memahami bahasa Arab merasa terpanggil untuk mengkomunikasikan informasi yang terkandung dalam kitab suci dan buku keislaman yang ditulis dalam bahasa Arab melalui kegiatan penerjemahan. Pada mulanya kegiatan tersebut dilakukan secara trial and error hingga akhirnya mereka memperoleh berbagai pengalaman dalam memecahkan persoalan penerjemahan. Kemudian pengalaman tersebut dijadikan prinsip, pedoman, dan acuan dalam melakukan kegiatan selanjutnya. Demikianlah, para penerjemah tersebut umumnya dibesarkan oleh pengalaman individual dan bukan merupakan hasil belajar secara formal.

Secara hukum, Alquran itu mubah diterjemahkan, tetapi hasil 
terjemahannyabukan merupakan karya otonom, sebagai tek yang dapat menggantikan nas sumbernya. Ia hanya sebagai sarana pendekatan untuk memahami firman Allah swt. ${ }^{5}$

Terjemahan mereka pada umumnya cukup baik sebagaimana dibuktikan oleh adanya penerbit yang berminat untuk mempublikasikan karya mereka dan adanya para pembaca. Namun, ada beberapa masalah yang sering dihadapi oleh penerjemah di antaranya berkenaan dengan (a) kegiatan penerjemahan itu sendiri yang memang sulit, (b) adanya perbedaan yang substansial antara bahasa Arab dan Bahasa Indonesia, (c) kurangnya penguasaan penerjemah terhadap bahasa penerima sehingga menimbulkan gejala interferensi, dan (d) kurangnya penguasaan penerjemah terhadap teori terjemah.

Lemahnya penguasaan bahasa Arab dan proses pemaknaannya akan membuat hasil penerjemahan keliru bahkan salah. Apa yang terjadi bila yang diterjemahkan adalah teks keagamaan? Tentu ini akan berakibat fatal bahkan dapat menimbulkan faham radikal. Sebagai contoh

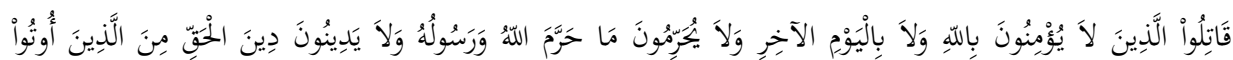

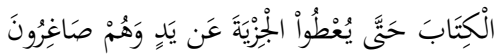

Ayat di atas jika dipahami tanpa melihat konteksnya, terutama

${ }^{5}$ Syihabuddin, Pendidikan dan Bahasa dalam Perspektif Agama (Bandung: UPI Press, 2019), 162. 
konteks saat ayat ini diturunkan atau tanpa melihat relasi dengan teks lainnya secara intertekstual, niscaya pembacanya akan menjadi pembunuh orang lain yang tidak seiman, bahkan dicap sebagai teroris. Boleh jadi kasus - kasus bom bunuh diri yang terjadi di Indonesia tempo hari seperti bom bali merupakan buah dari dari penerjemahan pemahaman yang tidak utuh terhadap ayat Alquran.

Berdasarkan uraian di atas, sangat penting upaya pelatihan dan workshop penerjemahan nas keagamaan bagi para da'i yang paling banyak berinterasi dengan masyarakat dan memiliki pengaruh yang signifikan dalam mengarahkan perilaku masyarakat. Da'i mesti menjadi pelopor dalam pemberian pemahaman yang benar terhadap masyarakat.

\section{Metode}

Pengabdian ini dilakukan dalam bentuk seminar dan workshop. Setelah pemarana secara teoretis, para peserta dibagi menjadi beberapa kelompok. Selanjutnya, diberi teks yang berpotensi melahirkan pemahaman radikal dan intoleransi. Kegiatan pengabdian ini dilaksanakan pada tanggal 16 Juli 2019 di Yayasan asSyifa al-Khoeriyah sebagai mitra dalam kegiatan riset dan pengabdian kepada masyarakat. Di samping itu, selama 3 bulan dilakukan pendampingan.

\section{Hasil dan Diskusi}

Sebagaimana telah dipaparkan diatas bahwa proses 
pendampingan dilakukan sejak tanggal 16 juli. Setelah selesai melaksanakan kegiatan pengabdian, disebarkan angket. Adapun data yang diperoleh adalah sebagai berikut

Saya bisa berbahasa Arab tulisan

23 responses

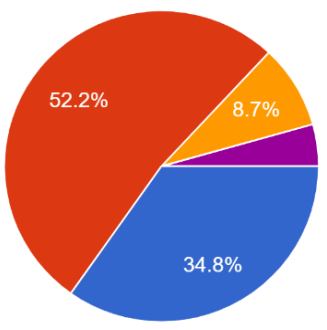

Sangat Setuju

Setuju

Ragu-ragu

Tidak Setuju

Sangat tidak setuju

Saya bisa berbahasa Arab lisan

23 responses

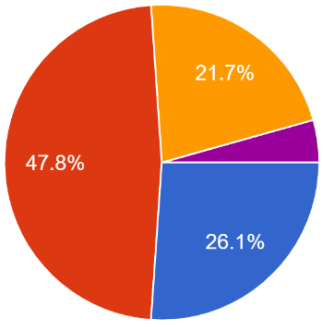

Sangat Setuju

Setuju

Ragu-ragu

Tidak Setuju

Sangat tidak setuju

Dari 23 responden, peserta yang bisa berbahasa Arab tulisan terdapat $85 \%$ dan $73.9 \%$ bisa berbajasa Arab lisan. Ini menunjukkan bahwa para peserta pada umumnya sudah memiliki dasar untuk 
memahami Alquran yang berbahasa Arab.

Radikalisme sangat berbahaya dalam kehidupan di masyarakat dan negara 23 responses

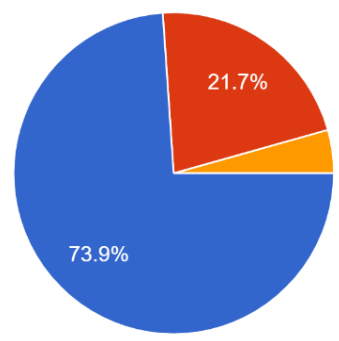

Sangat Setuju

Setuju

- Ragu-ragu

- Tidak Setuju

- Sangat tidak setuju

Mayoritas (95.6\%) mereka berpendapat bahwa radikalisme sangat berbahaya. Adapun sisanya (4.4\%) memandang ragu.

Intoleransi sangat berbahaya dalam kehidupan di masyarakat dan negara 23 responses

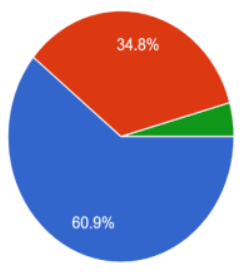

Sangat Setuju

Setuju

Ragu-ragu

Tidak Setuju

Sangat tidak setuju

Radikalisme bertujuan melakukan perubahan melalui pemaksaan dan kekerasan

23 responses

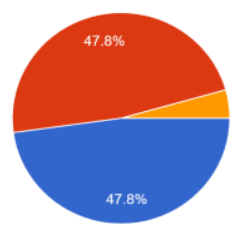

- Sangat Setuju

Setuju

Ragu-ragu

- Tidak Setuju

- Sangat tidak setuju 
Ciri Radikal menurut BNPT adalah yang mengkafirkan, berbuat kekerasan, intoleransi

23 responses

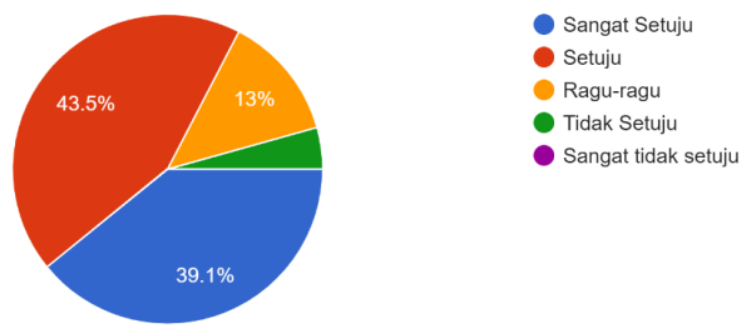

Ciri Radikal menurut BNPT adalah menggaungkan jihad 23 responses

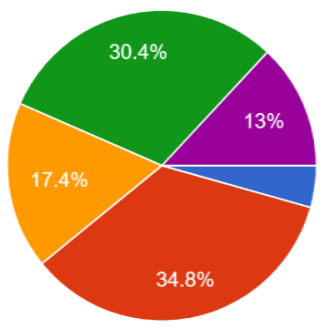

Sangat Setuju

- Setuju

Ragu-ragu

Tidak Setuju

- Sangat tidak setuju

Di dalam Alquran terdapat ayat yang berpotensi menyebabkan radikalisme 23 responses

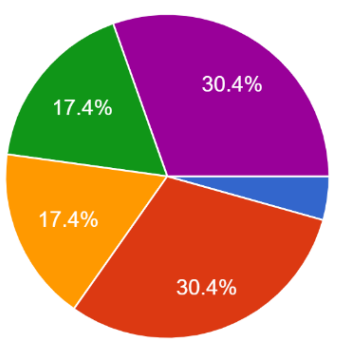

Sangat Setuju

Setuju

Ragu-ragu

Tidak Setuju

Sangat tidak setuju 
Di dalam Aquran banyak ayat tentang jihad

23 responses

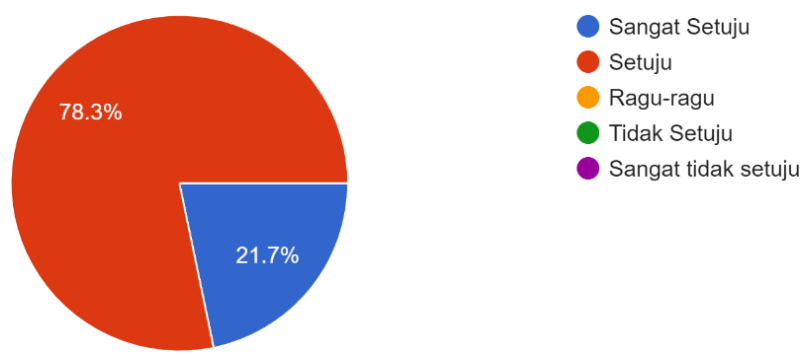

Ayat-ayat jihad sering dijadikan dasar perilaku radikal dan intoleransi

23 responses

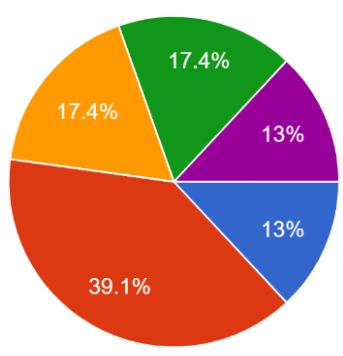

Sangat Setuju

Setuju

Ragu-ragu

Tidak Setuju

- Sangat tidak setuju

Memahami Alquran cukup dari terjemahan

23 responses

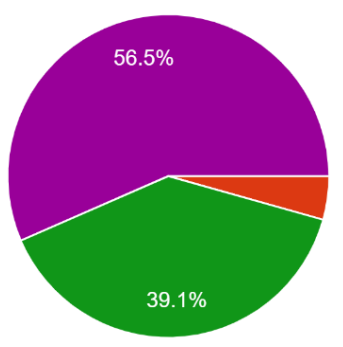

Sangat Setuju

Setuju

Ragu-ragu

Tidak Setuju

- Sangat tidak setuju 
Faktor ekonomi, kedangkalan keilmuan, ketidakpuasan, dendam, dan empati yang tinggi bida menjadi penyebab radikalisme dan intoleransi 23 responses

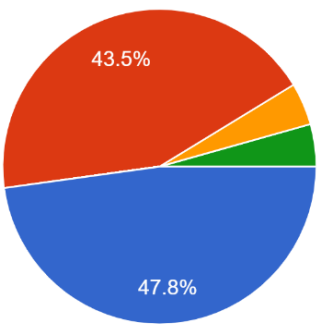

Pesantren dan rohis sumber radikalisme

\section{3 responses}

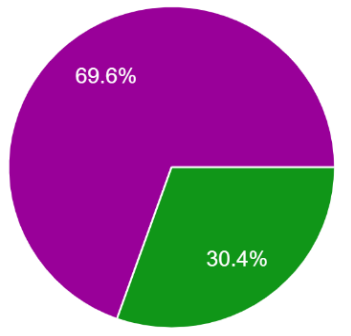

ISIS organisasi islam pejuang khilafah 23 responses

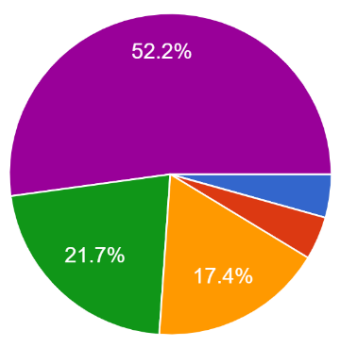

Sangat Setuju

Setuju

Ragu-ragu

Tidak Setuju

Sangat tidak setuju

Sangat Setuju

Setuju

Ragu-ragu

Tidak Setuju

Sangat tidak setuju
Sangat Setuju

Setuju

Ragu-ragu

Tidak Setuju

- Sangat tidak setuju 
Adapun upaya yang telah dilakukan para dai dalam menanggulangi radikalisme adalah sebagai berikut.

- Sebagai guru, upaya yang saya lakukan untuk mencegah intoleransi:

- Memberikan pemahaman yg baik kepada murid

- melatih murid untuk bertoleransi melalui pemahaman yang benar dan pembiasaan yang berkelanjutan

- Memahami, menerjemahkan dan menjelaskan nilai agama secara menyeluruh yang berkaitan dengan ibadah, akhlaq dan muamalah

- Sedikit-sedikit memberi pemahaman terhadap siswa tentang bahayanya paham radikal dan intoleransi

- Edukasi Peserta didik lebih bertoleransi

- memberi selingan materi kepada murid di kelas tentang bahaya intoleransimeningkatkan pemahaman tentang hidup kebersamaan

- Menjelaskan kepada murid untuk tidak mengambil mentah2 terjemahan Al Qur'an tapi harus mempelajari tafsirnya

- Memberi teladanMenambah pemahaman yang luas dan belajar dari sumber yang baik

- pemahaman seseorang sangat berpengaruh terhadap tindakannya, sehingga sbg guru, sangat penting menanamkan pemahaman yg baik dan benar ttg toleransi.

- Memberi faham ilmu Agama yang hanif dan benar disertai dalail 
yang kuat dan bersumber pada al quran, sunan, qiyas, dan ijtima'para ulama.

- Memberi pemahaman ideologi yg benar

- Mangaitkan materi pelajaran tertentu yg berhubungan dgn agama untuk saling menghargai perbedan.

- mengajarkan toleransi, memberikan teladan tentang toleransi

- Menjadikan islam rahmatan Lil alamin

- Memberikan pandangan yg tepat ttg agama

- Memberikan pemahaman saling menghargai dari mulai perbedaan bahasa, warna kulit, sampai kepada penyembahan

- Mengikuti tauladan baginda Nabi Muhammas Saw dalam bertoleransi

- Memahami lebih dalam pokok masalah dan berusaha mencegahnya lewat dunia pendidikan

- Mengajar kan ayat 2 alquran tdk hanya terjemahan gamblang saja

- berupaya membentengi diri dan anak didik dengan pemahaman agama yang komprehensif, serta menghindarkan diri dan anak didik dari sikap-sikap intoleran dengan tetap menjunjung tinggi nilai agama dan kebangsaan

- Memberikan edukasi terkait dengan perbedaan dan kebebasan dalam menentukan suatu pilihan

- Sebagai guru, upaya yang saya lakukan untuk mencegah 
radikalisme23 responses

- Memberikan pemahaman dan menjelaskan tentang ancaman radikalisme

- Memfasilitasi murid untuk belajar tuntas tentang islam

- Peningkatan tranparansi sistem dan pengembangan ekonomi masyarakat, revitalisasi teori dan praktek kehidupan sosial dalam membentuk peradaban ideal, pengembangan signifikan pada literasi global

- Sedikit-sedikit memberi pemahaman terhadap siswa tentang bahayanya paham radikal dan intoleransi

- Edukasi Peserta didik menghindari radikalisme

- memberi selingan materi kepada murid di kelas tentang bahaya radikalisme

- menyaring setiap informasi yang diterima

- Mengingatkan murid

- Mengajarkan bahasa Arab dengang benar

- Menambah pemahaman yang baik,menyebarkan dakwah islam yang baik hanif .

- pemahaman seseorang sangat berpengaruh terhadap tindakannya, sehingga sbg guru, sangat penting menanamkan pemahaman yg baik dan benar ttg islam rahmatan lil alamiin

- Memberikan penanaman nilai-nilai persatuan dan nasionalisme 


\section{Kesimpulan}

Berdasarkan hasil pendampingan sangat diperlukan berbagai workshop berkala penerjamahan bagi para dai atau guru-guru agama, khususnya yang berkaitan dengan penerjemahan teks keagamaan (ayat-ayat yang berpotensi menimbulkan pemahaman radikal dan intoleransi). Di samping itu, diperlukan sinergi antara Yayasan, universitas, dan kemenag untuk senantiasa melakukan kegiatan seperti ini secara sistematis.

\section{Daftar Pustaka}

Fitria, Vita "Konflik Peradaban Samuel P. Huntington (Kebangkitan Islam yang Dirisaukan?)", Humanika Vol. 9 (1) , Maret (2009), hal. $39-52$. Tersedia online: https://media.neliti.com/media/publications/18122-ID-konflikperadaban-samuel-p-huntington-kebangkitan-islam-yangdirisaukan.pdf

Syihabuddin, Pendidikan dan Bahasa dalam Perspektif Agama. Bandung: UPI Press, 2019

Wahid, Yenny. "Radikalisme di Indonesia Meningkat". https://www.republika.co.id/berita/nasional/umum/17/03/27/onh8 yv366-yenny-wahid-radikalisme-di-indonesia-meningkat, 2017. 
Zuhairi, Misrawi. “Ke Arah Islam Rahmatan Lil „Alamin, Tantangan dan Jawaban" dalam Seminar Islam Agama Dialogis dan Cinta Damai, 20 Januari 2013. 